\section{Publiczne konstruowanie historii. Przeszłość w prawicowej ikonografii}

Magdalena Saryusz-Wolska
Artykuł powstał

w zespole badawczym „Funkcjonalność historii w późnej nowoczesności" w Niemieckim Instytucie Historycznym w Warszawie.

TEKSTY DRUGIE 2016, NR 6, S. 326-345

DOI: 10.18318/td.2016.6.19

\title{
I
}

Opowiadanie historii odbywa się nie tylko za pośrednictwem słów, ale także obrazów, co Hayden White nazwał historiofotią (przez analogię do historiografii) ${ }^{1}$. Mimo że problem obrazowania przeszłości i wykorzystywania materiałów wizualnych w badaniach dyskutowany jest na gruncie metodologii historii od lat ${ }^{2}$, to teoretyczne rozważania nie zawsze przedkładają się na praktykę. Tylko nieliczne wizualne reprezentacje historii zyskują zainteresowanie badaczy. O ile wiele uwagi poświęca się dziś muzeom ${ }^{3}$ czy filmom

1 H. White Historiografia i historiofotia, przeł. Ł. Zaremba, w: Film i historia. Antologia, red. I. Kurz, Wydawnictwa UW, Warszawa 2008.

2 Przegląd tych dyskusji w polskojęzycznej literaturze przedmiotu znajduje się w: D. Skotarczak Historia wizualna, Wydawnictwo Naukowe UAM, Poznań 2012; P. Witek Andrzej Wajda jako historyk. Metodologiczne studium z historii wizualnej, Wydawnictwo UMCS, Lublin 2016; M. Saryusz-Wolska Ikony normalizacji. Kultury wizualne Niemiec 1945-1949, PWN, Warszawa 2015.

3 Por. m.in. A. te Heesen Theorien des Museum. Zur Einführung, Junius Hamburg, Hamburg 2012 (polskie tłumaczenie ukaże się w 2017 roku nakładem wydawnictwa Neriton); A. Ziębińska-Witek Historia w mu-

\author{
Magdalena Saryusz- \\ -Wolska - dr hab., \\ kulturoznawczyni \\ i socjolożka w In- \\ stytucie Kultury \\ Współczesnej Ut \\ oraz w Niemieckim \\ Instytucie Historycz- \\ nym w Warszawie. \\ Zajmuje się pamięcią \\ zbiorową i historią \\ wizualną. Opubliko- \\ wała m.in. Spotkania \\ czasu z miejscem. \\ Studia o pamięci \\ i miastach (2011) oraz \\ Ikony normalizacji. \\ Kultury wizualne \\ Niemiec 1945-1949 \\ (2014). Współredak- \\ torka m.in. Modi \\ memorandi.Leksykon \\ kultury pamięci (2014). \\ Kontakt: mswolska@ \\ poczta.onet.pl
}


historycznym ${ }^{4}$, to liczne, ale mniej spektakularne elementy ikonosfery (by użyć przydatnego pojęcia Mieczysława Porębskiego ${ }^{5}$ ), takie jak ilustracje prasowe, memy internetowe, wlepki, graffiti czy nawet t-shirty, funkcjonują na marginesach badań. W moim przekonaniu wynika to z nierozwiązanego sporu na temat obrazów jako źródeł historycznych ${ }^{6}$.

Mamy skłonność do takiego traktowania świadectw wizualnych jakby, w najlepszym razie, stanowiły uzupełnienie zapisów werbalnych, a nie samodzielną wypowiedź: autonomiczny dyskurs, zdolny do mówienia o rzeczach inaczej niż dyskurs werbalny, oraz o rzeczach, o których można się wypowiadać tylko za pomocą obrazów wizualnych.?

- pisał White. Diagnoza ta nie straciła na aktualności, mimo że ma dziś prawie trzydzieści lat. Współczesna kultura masowa produkuje niezliczone ilości obrazów historii, których nie da się sprowadzić do roli „uzupełnienia świadectw werbalnych". Obrazy te tworzą dzisiejsze wyobrażenia o przeszłości.

Myśl o kreatywnym potencjale ikonosfery, o jej zdolności do wytwarzania zarówno wyobrażeń o świecie, jak i samego świata, nie jest nowa. Pojawia się u klasyków anglosaskich studiów wizualnych (visual culture studies) i niemieckiej nauki o obrazie (Bildwissenschaft).W.J.T. Mitchell mówi w tym kontekście o obrazach jako "quasi-agentach"8 , a Horst Bredekamp o ,aktach obrazu" jako analogii do „aktów mowy" . Niemiecki badacz Gerhard Paul zastosował ten trop w odniesieniu do konstruowania historii: „Obrazy to więcej niż źródła, przedstawiające zewnętrzne okoliczności czy zdarzenia. Obrazy to więcej niż media, które [...] przekazują lub tworzą znaczenia. Obrazy posiadają bowiem

zeach. Studium ekspozycji Holokaustu, Wydawnictwo UMCS, Lublin 2011; K. Jagodzińska Czas muzeów w Europie Środkowo-Wschodniej. Muzea i centra sztuki współczesnej, Międzynarodowe Centrum Kultury, Kraków 2014.

Przegląd najważniejszych prac oferuje antologia Film i historia...

5 M. Porębski Ikonosfera, PIW, Warszawa 1972.

6 Więcej na ten temat w: P. Burke Naoczność. Materiały wizualne jako świadectwa historyczne, przeł. J. Hunia, Wydawnictwo UJ, Kraków 2012.

7 H. White Historiografia i historiofotia..., s. 118.

8 W.J.T. Mitchell Czego chcq obrazy?, przeł. Ł. Zaremba, NCK, Warszawa 2013, s. 79.

9 H. Bredekamp Theorie des Bildakts, Suhrkamp, Frankfurt am Main 2010, s. 51. 
zdolność kształtowania rzeczywistości"10 . Koncepcję tę można uzupełnić, odwołując się do archeologii wiedzy. Paulowi nie chodzi bowiem o tworzenie historii jako takiej, ale raczej o konstruowanie wiedzy historycznej; o praktyki, które zmierzają do takiego budowania wyobrażeń o przeszłości, by z biegiem czasu ukształtowały common sense, przeniknęły dyskursy tak mocno, że w końcu staną się niezauważalne.

Obserwujemy w tej chwili przełomowy moment, w którym zmienia się myślenie historyczne. Historia afirmatywna, która wpisuje się w „paradygmat romantyczny" i podkreśla rolę narodu w procesach dziejowych, jest w Polsce trwałą formą dyskursu o przeszłości. Zarazem jednak po 1989 roku poszerzała się przestrzeń dla historii krytycznej, stawiającej zbiorowe bohaterstwo pod znakiem zapytania, eksponującej dyskursy emancypacyjne i perspektywy grup wykluczonych. Badania na temat udziału Polaków w Holokauście czy historii płci, choć wywoływały dyskusje, stanowiły równoprawny element przestrzeni publicznej. W ostatnim czasie odnotowujemy natomiast powrót do hegemonii dyskursu historii afirmatywnej, przy czym nie jest to zjawisko związane wyłącznie z wyborami prezydenckimi i parlamentarnymi w 2015 roku. Uproszczeniem byłoby stwierdzenie, że przejęcie władzy przez prawicę skutkowało nowymi narracjami historycznymi. Zwycięstwo tej formacji należałoby raczej postrzegać jako jeden ze skutków, a nie przyczynę, zmian. Narodowy Dzień Pamięci żołnierzy Wyklętych jest bowiem obchodzony od 2011 roku; wszystkie rządy od 2006 roku wspierały budowę Muzeum Historii Polski jako „muzeum wolności”; w 2010 roku TVP wyprodukowała serial Sprawiedliwi eksponujący historię Żegoty i podający w wątpliwość współudział Polaków w Zagładzie Żydów; wreszcie: festiwal „Niepokorni, Niezłomni, Wyklęci" odbywał się w 2016 roku po raz ósmy. Takich przykładów można by wymienić znacznie więcej. Kiedy więc w 2015 roku partia Prawo i Sprawiedliwość przejmowała władzę, miała doskonale przygotowany grunt pod rozbudowę afirmatywnej polityki historycznej. Dużą rolę w tym procesie odegrały media sprzyjające nowemu rządowi, w szczególności zaś - co wykażę poniżej - obrazy przez nie rozpowszechniane.

Ikonografia odwołująca się do historii realizuje nie tylko potrzeby polityczne, ale też tożsamościowe i ekonomiczne. Jako przykład można podać spopularyzowany symbol „Polski walczącej”. Na wspomnianym wyżej VIII festiwalu „Niepokorni, Niezłomni, Wyklęci” wyróżnienie otrzymał film Marii

10 G. Paul Visual History. Version 2.0, http://docupedia.de/zg/Visual_History_Version_2.o_Gerhard_Paul (12.09.2016). 
Wiśnickiej i Andrzeja Wyrozębskiego Kotwica PW - tylko trzy maźnięcia, opowiadający historię tego znaku oraz nakłaniający do używania go współcześnie. Trudno się zatem dziwić, że widać go na murach, ubraniach, tatuażach, zabawkach dla dzieci czy samochodach (nie tylko tych na warszawskich rejestracjach). „Obecnie symbol ten jest elementem rozpoznawczym wielu środowisk patriotycznych" - czytamy na stronie internetowego sklepu grafikapatriotyczna.pl. Kogo dokładnie reprezentują „środowiska patriotyczne” i jakie mają cele - tego możemy się jedynie domyślać. Niemniej istotny jest ekonomiczny potencjał ikonografii patriotycznej. Z tej samej strony internetowej dowiadujemy się, że branża produkująca te obrazy stale się rozwija.

Widoczny na przykładzie popularności „kotwicy” splot potrzeb społecznych, polityki i ekonomii sprawia, że o motywach historycznych w publicznej ikonosferze należałoby mówić w kontekście przemian społeczeństwa ponowoczesnego i gospodarki neoliberalnej. Rama pamięci zbiorowej wydaje się natomiast mniej przydatna, choćby dlatego, że różne grupy promują różne obrazy, a w pojęciach takich jak „pamięć zbiorowa” czy „pamięć kulturowa” zawsze kryje się tendencja do uogólniania, sugestia, że cała społeczność pamięta to samo w ten sam sposób. Jest to poniekąd konsekwencja szerokiej zgody na uznanie modelu Maurice’a Halbwachsa za założycielską teorię pamięci zbiorowej. Pokazywał on bowiem, że w wyniku działania społecznych ram pamięci jednostkowe wspomnienia podlegają ujednoliceniu i wtłoczeniu we wspólny schemat narracyjny. W tej tradycji pamięć zbiorowa posługuje się wielkimi kwantyfikatorami, odwołuje się do wspólnot, wynika z przynależności klasowej, religijnej czy rodzinnej. Różnice między odmiennymi wyobrażeniami historii wśród członków tych grup schodzą natomiast na dalszy plan. Ponadto idea pamięci społecznej i zbiorowej zawsze jest metaforą - jak przed laty zauważała Barbara Szacka11. Otwiera to pole do zajmowania się pojęciami oraz do ich najróżniejszych interpretacji, natomiast problem wykorzystywania historii w celach legitymizacyjnych nie jest metaforyczny, lecz jak najbardziej realny. Aby zrozumieć mechanizmy polityki i propagandy historycznej, nie należy - moim zdaniem - wikłać się w metadyskursy, lecz przyjrzeć się konkretnym praktykom medialnym, prawnym czy finansowym. Niektóre aspekty omawianych poniżej obrazów można by interpretować przez odwołanie do przemysłu pamięci ${ }^{12}$ - zarówno w sensie

B. Szacka O pamięci społecznej, "Znak” 1995 nr 5, s. 68.

P.T. Kwiatkowski Przemysłpamięci, w: Modi memorandi. Leksykon kultury pamięci, red. M. Saryusz-Wolska, R. Traba, współpr. J. Kalicka, Scholar, Warszawa 2014. 
utowarowienia przeszłości, jak i jej produkcji. Wieloznaczność samego pojęcia „pamięć” oraz jego konotacje związane z przeważnie oddolnym i ogólnym charakterem procesów utrwalania przeszłości sprawiają jednak, że nie jest ono właściwą kategorią analityczną.

Szukając alternatywy do „pamięci” warto rozważyć dwie koncepcje: a) historię w przestrzeni publicznej, która zadomowiła się w języku polskim jako odpowiednik angielskiego public history ${ }^{13}$, oraz b) historię w kulturze współczesnej - pod tym hasłem realizowane są projekty badające obecność i funkcje przeszłości w ponowoczesnej kulturze masowej ${ }^{\mathbf{1 4}}$. Przedstawiciele obu podejść nie zadają pytań typowych dla badań pamięci: kto, co, jak pamięta? Wychodzą raczej od analizy dyskursów i obiektów historycznych (historyzujących) w przestrzeni publicznej i kulturze masowej oraz zadają pytania o ich społeczne, ekonomiczne i polityczne funkcje. Umieszczanie „kotwicy” w widocznych miejscach nie musi być przecież przejawem pamięci zbiorowej. Prawdopodobnie większość osób, która to czyni, nie ma żadnego osobistego związku z powstaniem warszawskim. Niewykluczone też, że wiele z nich nie będzie w stanie przyporządkować go do żadnej daty (w badaniu CBOS z kwietnia 2016 roku tylko 8\% Polaków uznało powstanie warszawskie za jedno z najważniejszych wydarzeń w dziejach Polski w XX i XXI wieku ${ }^{15}$ ). Trudno na podstawie „kotwic” na murach, samochodach i koszulkach mówić o tym, jakie grupy jak pamiętają wydarzenia z 1944 roku. Warto natomiast wskazać samą ich obecność w publicznej ikonosferze, zadawać pytania o ich potencjał polityczny, gospodarczy i tożsamościowy.

\section{II}

Gadżety patriotyczne, murale czy memy internetowe stanowią zbyt rozproszony zbiór obrazów, by można było na ich podstawie prowadzić

13 Th. Cauvin Public History. A Textbook of Practice, Routledge, London-New York 2016. Od 2014 roku Uniwersytet Wrocławski oferuje studia licencjackie "historia w przestrzeni publicznej". Analogiczną nazwę nosi długoterminowy projekt Centrum Badań Historycznych PAN w Berlinie.

14 Warto tu wskazać na dwie wydane publikacje i jedną planowaną: Historia w kulturze współczesnej. Niekonwencjonalne podejścia do przeszłości, red. E. Solska, P. Witek, M. Mazur, Edytor.org, Lublin 2011; Historia w wersji popularnej, red. I. Kiec, I. Kowalczyk, Katedra Wydawnictwo Naukowe, Gdańsk 2016; Funkcje historii w kulturze późnej nowoczesności, red. M. Řezník i in., Kraków 2017 (w przygotowaniu). 
ustrukturyzowane analizy. Relatywnie niewielkim, łatwo porównywalnym i zarazem względnie reprezentatywnym materiałem wizualnym są natomiast okładki magazynów ilustrowanych. Funkcjonują one w trzech rodzajach przestrzeni: publicznej, gdy widać je w kioskach i na wystawach salonów prasowych; prywatnej, gdy czytane są w domu; wirtualnej, gdy reprodukowane są w Internecie. Ich rola nie sprowadza się wyłącznie do zapowiedzi treści publikowanych wewnątrz czasopism. Aby wspierać sprzedaż poszczególnych tytułów, okładki muszą przyciągać wzrok, wybijać się z pozostałej oferty.„Wyrazista okładka to 20-30 tys. sprzedanych egzemplarzy więcej" - deklaruje Rafał Kalukin z „Newsweek Polska”"16. Powinny zatem mówić same za siebie, prezentować poglądy redakcji w taki sposób, aby można je było rozpoznać nawet bez zaglądania do środka. Redakcje, świadome ideologicznej oraz ekonomicznej istotności tego medium, same wdają się w „walkę na okładki”, czego przykładem były wydania „Polityki” i „Do Rzeczy” z połowy czerwca 2016 roku. Po tym jak „Polityka” (2016 nr 24) zapowiedziała materiały poświęcone nacjonalistycznym bojówkom, przedstawiając na okładce kij bejsbolowy, na którym powiewała polska flaga, „Do Rzeczy” (2016 nr 24) odpowiedziało, kilka dni później, okładką przedstawiającą analogiczny kij bejsbolowy oraz flagę ze swastyką i obliczem Hitlera. Podpis brzmiał: „Hitlerem w prawicę. Groźna pałka, którą lewicowy Salon okłada wrogów".

Przyglądając się okładkom „Uważam Rze”,,W Sieci” i „Do Rzeczy”, szukam odpowiedzi na pytania: jaką historię przedstawiają i w jakim celu to robią. Mimo że środowiska prawicowe na ogół odrzucają założenia konstruktywizmu i odwołują się do jednej „prawdy historycznej"17, to dobierając materiał ikonograficzny w kontrolowanych przez siebie mediach, formują własną wizję przeszłości, dążąc do utrwalenia hegemonii nowego dyskursu. „Odkłamywanie historii”, ,eksponowanie polskiego punktu widzenia” - o czym mówią politycy - jest niczym innym, jak konstruowaniem historii na nowo. Zdarza się więc, że przedstawiciele prawicy jawnie domagają się rewizji faktów ustalonych w wielu niezależnych badaniach historycznych ${ }^{18}$. W lipcu 2016 roku, przy okazji 75. rocznicy zbrodni w Jedwabnem, tygodnik „W Sieci”

16 Zob. http://obserwatorium.kulturaliberalna.pl/raport/kto-jest-w-polsce-radykalem-za-kulisami-tygodnikow/ (12.09.2013).

17 Por. m.in. M. Nykiel Prawda historyczna nareszcie ma głos, http://wpolityce.pl/historia/285573-prawda-historyczna-nareszcie-ma-glos-trzeba-jeszcze-odklamac-jedwabne-i-dziejowasprawiedliwosc-stanie-sie-faktem-prezydentura-dudy-daje-nadzieje?strona=3 (04.10.2016).

Por. tamże. 
(2016 nr 27) opublikował okładkę ze zdjęciem płonącej stodoły i napisem: "Jedwabne trzeba zbadać od nowa". Nawiasem mówiąc, retoryka „docierania do prawdy" uwidacznia się dziś przede wszystkim w tekstach i obrazach, które dotyczą stosunków polsko-żydowskich. Tymczasem, kiedy w połowie pierwszej dekady XXI wieku rodził się spór o kształt pamięci zbiorowej, toczony między zwolennikami historii afirmatywnej i krytycznej, głównym tematem były relacje między Polakami i Niemcami, zwłaszcza w związku z projektami upamiętniania wysiedlonych ${ }^{19}$.

Ilustrowana prasa społeczno-polityczna przeżywała rozkwit w Polsce po 1989 roku - wtedy właśnie tygodnik „Wprost”, który ukazywał się od 1982 roku jako tytuł lokalny, pojawił się na rynku ogólnopolskim. Publikując śmiałe okładki, oparte na technice fotomontażu i niewyszukanych skojarzeniach, proponując komiksy polityczne i sukcesywnie zwiększając proporcje ilustracji do tekstu, redaktorzy „Wprost” kształtowali w Polsce standardy wizualizacji najróżniejszych tematów. W swojej burzliwej historii tygodnik niejednokrotnie balansował na granicy prasy politycznej i bulwarowej. Od czasu, gdy ukazują się „Uważam Rze”, „W Sieci” i „Do Rzeczy”, stracił prawie trzy czwarte nakładu i dziś należy do tej samej spółki, co ostatni z wymienionych tytułów.

W 1995 roku „Polityka” przeszła na format magazynowy, co w owym czasie przyczyniło się do dużego sukcesu tygodnika. Sześć lat później koncern Axel Springer wprowadził do Polski tygodnik „Newsweek Polska”. Dopiero w 2011 roku pojawienie się miesięcznika „Uważam Rze” zaburzyło (jego czytelnicy powiedzieliby: przywróciło) równowagę na polskim rynku politycznych magazynów ilustrowanych. Od 2012 roku zaczął ukazywać się tygodnik "W Sieci”, a od 2013 roku „Do Rzeczy” - który przejął część dotychczasowego zespołu „Uważam Rze”.,W Sieci” oraz „Do Rzeczy” sprzedają, odpowiednio, około 80.000 i 70.000 egzemplarzy ${ }^{20}$. Jest to wprawdzie około $40 \%$ mniej niż w przypadku „Newsweeka” i „Polityki”, ale wpływ mediów trudno dziś oceniać po samym tylko nakładzie prasy. Warto zauważyć, że trzy czasopisma, które są dziś jednoznacznie kojarzone z prawicą i same określają się mianem konserwatywnych, powstały podczas drugiej kadencji rządów Platformy Obywatelskiej. Kierując się zarówno kryterium nakładu, jak i kształtowania

19 Por. m.in. Pamięć i odpowiedzialność, red. R. Kostro, T. Merta, Ośrodek Myśli Politycznej - Centrum Konserwatywne, Kraków-Wrocław 2005; R. Traba Historia - przestrzeń dialogu, Instytut Studiów Politycznych PAN, Warszawa 2006. 
dyskursu politycznego ${ }^{21}$, trudno uznawać dziś „Uważam Rze”, „W Sieci” i „Do Rzeczy” za media niszowe, „niepokorne” lub prasę „drugiego obiegu” - jak ich zwolennicy nazywali je w pierwszych latach istnienia, sugerując tym samym, że ich lektura grozi sankcjami. Tytuły te w krótkim czasie osiągnęły ważną pozycję na rynku i można zaryzykować tezę, że wpłynęły na wynik wyborów prezydenckich i parlamentarnych w Polsce w 2015 roku.

„Uważam Rze”, „W Sieci” oraz „Do Rzeczy” zdecydowanie częściej niż konkurencja - „Polityka” czy „Newsweek Polska” - odwołują się do motywów historycznych. Jest to zapewne konsekwencja przekonania środowisk konserwatywnych, że - jak pisał przed laty Dariusz Gawin - „należy podejmować wysiłki na rzecz wypracowania modelu polskiej polityki historycznej. [...] Inaczej nie da się odbudować więzi łączącej na powrót Polaków we wspólnotę polityczną, zdolną do aktywnego działania w historii"22. O ile wszystkie większe tygodniki i miesięczniki społeczno-polityczne wydają dziś specjalne dodatki historyczne, to w wypadku trzech wspomnianych tytułów zainteresowanie przeszłością równie intensywnie przejawia się w głównych tytułach. Polityka historyczna jest w nich równie obecna (a może nawet bardziej), co polityka społeczna czy polityka ekonomiczna. Od początku swej działalności „W Sieci” czy „Do Rzeczy” wykorzystują motywy historyczne do kształtowania wizerunku „wrogów”. Przełomem była okładka „W Sieci” (2013 nr 41) przedstawiająca Tomasza Lisa w stroju przypominającym mundur SS, z różańcem, krwią na rękach i podpisem: „Prawie jak Goebbels”, która wywołała zdecydowany sprzeciw w mediach takich jak „Gazeta Wyborcza”, „Polityka” czy „Newsweek Polska”. W tym ostatnim wypadku reakcja była oczywista, gdyż chodziło o redaktora naczelnego tygodnika. Wprawdzie Lis wygrał proces o naruszenie dóbr osobistych, jaki wytoczył wydawcy „W Sieci”, ale wyrok zapadł dopiero dwa lata po publikacji okładki. W tym czasie tygodnik zdążył już zbudować swoją markę i utrwalić silnie emocjonalne motywy historyczne w publicznej ikonosferze.

Sięganie do motywów historycznych, w szczególności zaś do nazizmu, na okładkach polskiej prasy nie jest nowe. Podobnie jak w wypadku

21 Pisząc o "dyskursie politycznym", posługuję się pojęciem Marka Czyżewskiego, Andrzeja Piotrowskiego i Sergiusza Kowalskiego, którzy twierdzą, że jest to odmiana dyskursu elit symbolicznych (dziennikarzy, intelektualistów, artystów, a także polityków) na tematy polityczne. Por. M. Czyżewski, A. Piotrowski, S. Kowalski (red.) W stronę teorii dyskursu publicznego, w: Rytualny chaos. Studium dyskursu publicznego, WAiP, Warszawa 2010. 
kształtowania ikonografii politycznej, pionierem tej strategii był tygodnik „Wprost”. Do najbardziej znanych i zarazem skandalizujących okładek, epatujących porównaniami do historii, należał portret Andrzeja Leppera jako Hitlera (2002 $\mathrm{nr}$ 21) oraz Eriki Steinbach jako esesmanki z Gerhardem Schröderem na plecach (2003 nr 38). Skądinąd ikonografia odwołująca się do nazizmu jest obecnie wyjątkowo często reprodukowana. Publikowanie wizerunku Hitlera i nazistowskich symboli, nie zawsze w kontekście krytycznym, nie wywołuje dziś żadnych reakcji. Tylko w 2015 i 2016 roku Adolf Hitler aż czterokrotnie pojawił się na okładkach miesięcznika „Uważam Rze Historia” (2015 nr 3, $2016 \mathrm{nr}$ 2) (il. 1) oraz tygodników „W Sieci” (2016 nr 24) i „Wprost”

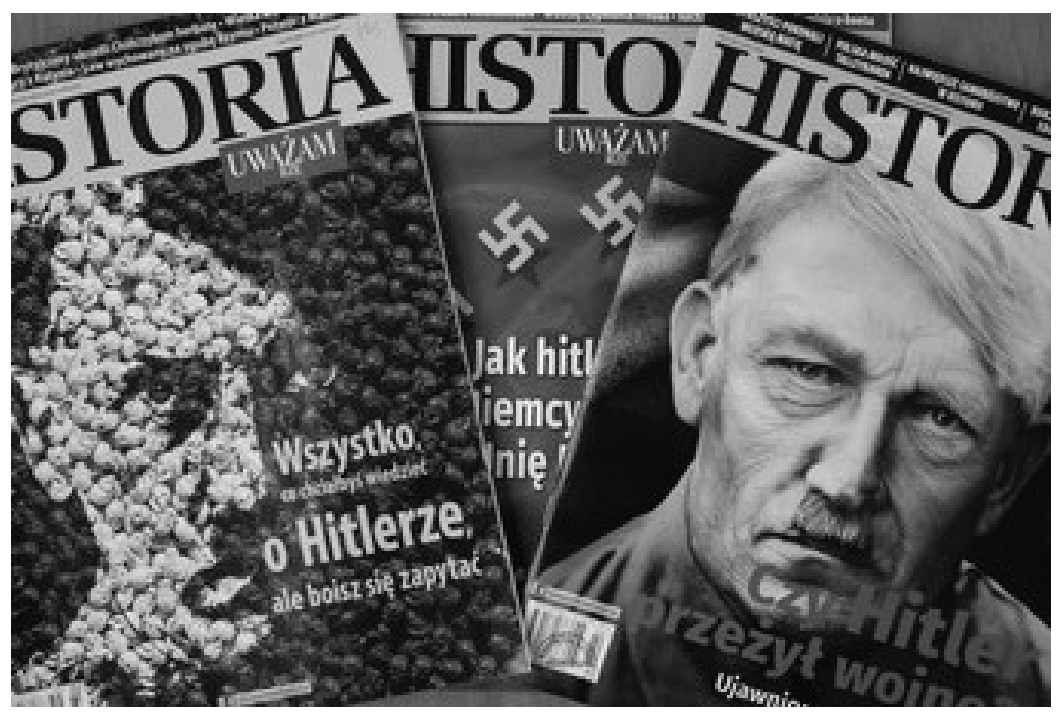

il. 1.: OBSESJE NAZIZMU. „Uważam Rze Historia”, lewa strona: 2015 nr 3, środek: 2015 nr 11; prawa strona: 2016 nr 2. Fot. własna.

(2016 nr 2). Ponadto wielokrotnie przedstawiano symbole nazistowskie, takie jak swastyki czy mundury. Trudno powiedzieć, na ile jest to zabieg celowy, analogiczny do popytu na liczne publikacje książkowe o przywódcy Trzeciej Rzeszy ${ }^{23}$, na ile zaś przejaw nieświadomej obsesji. Niezależnie od

23 Por. m.in.: Ch. Schroeder Byłam sekretarkq Adolfa Hitlera, przeł. M. Podwysocka, Bellona, Warszawa 1999; R. Peter Adolf Hitler: koniec legendy, przeł. N.N., Von Borowiecky, Warszawa 2005; L. Rees Złowroga charyzma Adolfa Hitlera: miliony prowadzone ku przepaści, przeł. K. Masłowski, Prószyński Media, Warszawa 2013. 
intencji jego rezultatem jest wzrost liczby symboli nazistowskich w publicznej ikonosferze - zwłaszcza na półkach i wystawach księgarni i salonów prasowych.

Posługiwanie się techniką fotomontażu na okładkach ma konsekwencje dla budowania spójnych wyobrażeń o przeszłości. W stosunku do klasycznego montażu różnica polega na tym, że narracja nie powstaje przez zestawienie obrazów w ciąg, lecz przez nałożenie jednego na drugi. Mechanizm jest jednak ten sam: z połączenia dwóch różnych znaków tworzy się nowy sens. W teorii montażu atrakcji Siergej Eisenstein pisał o „kojarzeniu dwóch elementów"24, najlepiej skonfliktowanych, niekoniecznie zaś o ich następstwie, głosił też, że celem widowiska jest kształtowanie nastroju widza, a „atrakcją" nazywał „każdy agresywny moment widowiska”25. Medium okładki przewiduje jednak także inną, bardziej tradycyjną formę montażu, na którą składają się cykle obrazów. Wprawdzie rzadko zdarza się, by dwie kolejne okładki były obecne w tej samej przestrzeni publicznej, ale na stronach internetowych poszczególnych czasopism, w dziale „archiwum”, zobaczymy szereg okładek, jedna obok drugiej. Można to uznać za wariację na temat klasycznego montażu, którego celem jest budowanie narracji w sposób możliwie przezroczysty, nierzucający się w oczy oglądającemu. Potencjał łączenia obrazów w ciąg dla budowania opowieści o historii podkreślał już zresztą White: „sekwencje ujęć i stosowanie montażu czy zbliżeń mogą służyć orzekaniu równie skutecznie, jak wyrażenia, zdania czy nawet sekwencje zdań w dyskursie mówionym lub pisanym"26.

Wskazując na intermedialne zapożyczenia omawianych tu obrazów, warto zwrócić uwagę na wykorzystywanie konwencji wizualnych, typowych dla kultury popularnej. „Do Rzeczy Historia” regularnie publikuje okładki inspirowane stylistyką komiksu (rysunki z użyciem twardych konturów, wyrazistych gestów itp.), „W Sieci Historii” zaś nawiązuje do gier komputerowych. Wykorzystuje np. dynamicznie skomponowane obrazy, przypominające kadry z wojennych Role Playing Games. Ponadto pojawiają się typowi bohaterowie popkultury, np. Superman („Do Rzeczy” 2016 nr 7) (il. 2) czy postaci z „Gwiezdnych Wojen”.Tygodnik „W Sieci” (2016 nr 5) przedstawiał premier Beatę Szydło na tle pojazdów kosmicznych oraz napis „Jasna strona mocy

\footnotetext{
24 S. Eisenstein Wybór pism, przeł. M. Kumorek, Wydawnictwa Artystyczne i Filmowe, Warszawa 1968, s. 308. 


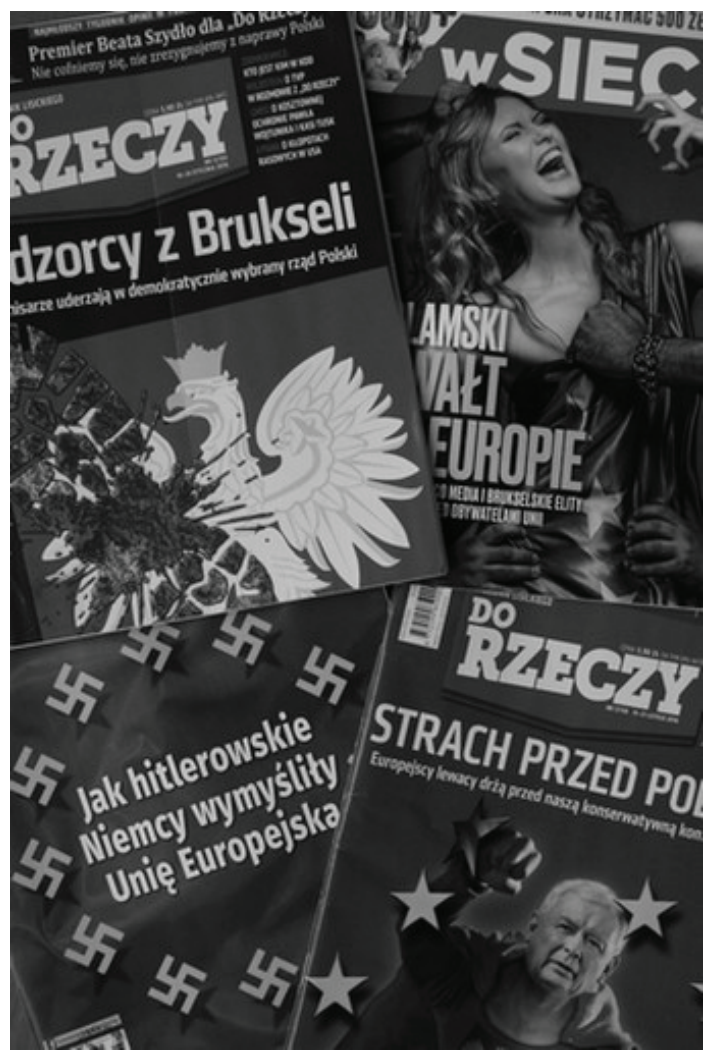

il. 2.: EUROPA JAKO WRÓG. Górny rząd lewa strona: „Do Rzeczy” 2016 nr 3, górny rząd prawa strona: „W Sieci” 2016 nr 7, dolny rząd lewa strona: „Uważam Rze Historia” 2015 nr 11, dolny rząd prawa strona: „Do Rzeczy” 2016 nr 7. Fot. własna. to my". Podobnie jak w wypadku praktyk narratywistycznych, mamy tu do czynienia $\mathrm{z}$ paradoksem. Konwencja oparta na przesadzie, nadmiernej teatralności, jaskrawych kolorach i nieadekwatnym - na pierwszy rzut oka - zestawianiu poważnych tematów i lekkiej formy zdaje się bowiem odwoływać do kampu ${ }^{27}$. Wewnętrzna sprzeczność tej strategii polega na tym, że kamp narodził się jako estetyczna praktyka walki z kulturą dominującą $\mathrm{i}$, artykulacja tożsamości homoseksualnych". ${ }^{28}$ Wykorzystywanie go dla wzmocnienia tradycji, postaw konserwatywnych czy

wartości chrześcijańskich samo w sobie zasługuje więc na uwagę. Co więcej, historia przedstawiana w polu kultury popularnej sprowadza się do rozrywki. Przez cytaty z komiksów, gier komputerowych i filmów przygodowych bohaterowie włączani są w binarny schemat walki dobra ze złem. My działamy tu po stronie dobra; oni po stronie zła.

27 Za sugestię na temat kampowego charakteru omawianych tu obrazów dziękuję Przemysławowi Czaplińskiemu.

28 P. Czapliński Kamp - gry antropologiczne, w: Kamp. Antologia przekładów, red. P. Czapliński, A. Mizerka, Universitas, Kraków 2012, s. 10. 
III

Jaki obraz „swoich" i „obcych”, „przyjaciół” i „wrogów” wyłania się z analizowanego materiału? Wrogowie to Niemcy i Rosjanie, i komuniści, na dalszym planie znajdują się Żydzi. Do najbardziej radykalnych obrazów, utożsamiających Niemców ze złem, należała okładka „Uważam Rze Historia” (2015 nr 9) przedstawiająca Angelę Merkel na tle bramy z napisem „Arbeit mach frei”, trzymającej worek ze złotem. Obok widniał napis: „Złodzieje Europy. Jak Niemcy zbudowali dobrobyt dzięki II wojnie światowej", sugerujący, że dzisiejsza kondycja niemieckiej gospodarki została wypracowana kosztem m.in. polskich ofiar i strat wojennych. O ile obraz ten przeszedł właściwie bez echa (być może dlatego, że podobna ikonografia pojawiała się wcześniej w Grecji podczas kryzysu finansowego), to okładka „Wprost” (2016 nr 1), powtórzona później w nieco łagodniejszej formie przez „W Sieci” (2016 nr 2), była szeroko komentowana nie tylko w Polsce, ale i za granicą (il. 3). „Wprost” przemon-

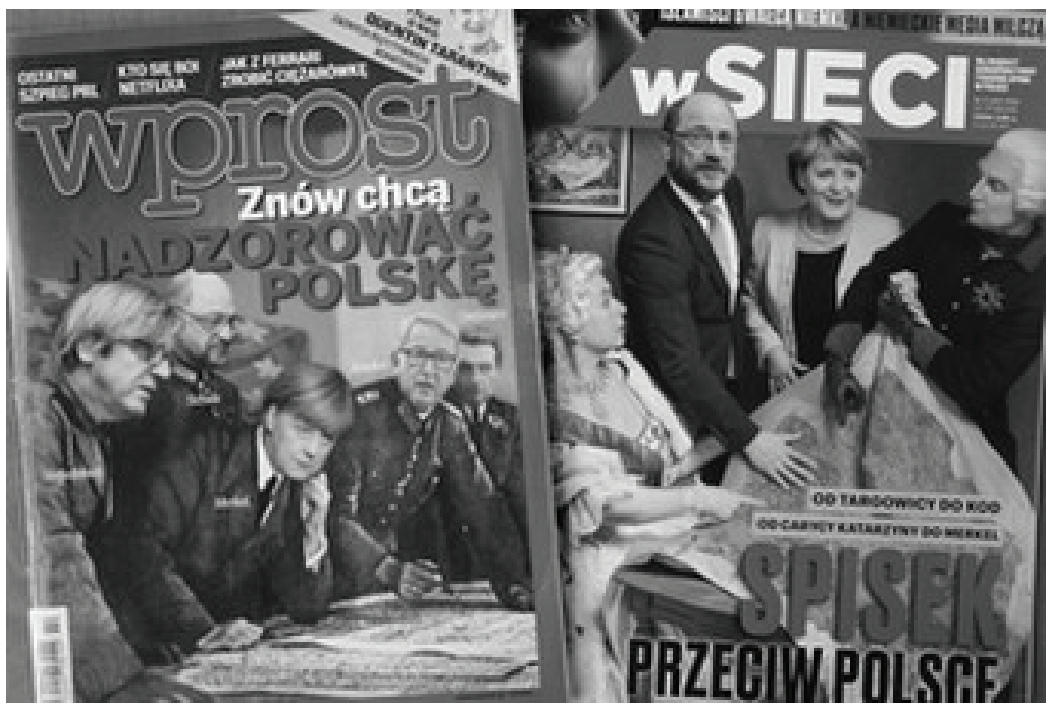

il. 3.: NADZÓR Z NIEMIEC (I ROSJI). Lewa strona: „Wprost” 2016 nr 2, prawa strona: „W Sieci” 2016 nr 2. Fot. własna.

tował znaną fotografię Adolfa Hitlera, Benito Mussoliniego, marszałka Wilhelma Keitela i generała Alfreda Jodla, wklejając w nią twarze Angeli Merkel, Martina Schulza, Guy Verhofstadta, Günthera Oettingera i Jean-Claude'a Junckera. Wszystkie postaci pochylały się nad mapą. „W Sieci” z kolei wykorzystał analogiczny motyw, ale wprowadził inne postaci: Fryderyka II 
Wielkiego i Katarzynę Wielką. W podpisach oba obrazy sugerowały, że obce mocarstwa nadzorują Polskę lub spiskują przeciwko niej. Pretekstem była wypowiedź Martina Schulza - marginalna uwaga o długości kilkunastu sekund, wygłoszona podczas dziewięciominutowego wywiadu radiowego poświęconego sytuacji we Francji po wyborach lokalnych. Komentując brak publikacji wyroku Trybunału Konstytucyjnego przez polski rząd, Schulz użył słów „sytuacja o charakterze zamachu stanu"29.

W szerszej perspektywie należy powyższe okładki postrzegać na tle kryzysu idei europejskiej w Polsce. Doskonale ilustruje to listopadowy numer „Uważam Rze Historia” z 2015 roku, przedstawiający flagę Unii Europejskiej, na której zamiast złotych gwiazdek widnieją złote swastyki oraz napis „Jak hitlerowskie Niemcy wymyśliły Unię Europejską". Zastosowaną tu retorykę można by określić mianem „pseudo-przeciw-historii”. Nie jest to bowiem przeciw-historia w Foucaultowskim sensie historii emancypacyjnej, lecz w prostym znaczeniu negowania faktów historycznych. Przedstawienie swastyk zamiast gwiazdek to otwarty gest sprzeciwu wobec Unii Europejskiej. W ten sposób redakcja sugeruje, jakoby Unia Europejska była zbrodniczym i totalitarnym systemem politycznym. W argumentacji tej, podnoszącej status Polski jako narodu „ciemiężonego" przez zewnętrzne siły, brakuje odwołań do faktycznych źródeł zjednoczonej Europy, które bazowały na sprzeciwie wobec totalitaryzmu i wojny. Podobny chwyt, aczkolwiek bez wyraźnych nawiązań do nazizmu, pojawił trzy miesiące później na okładkach „Do Rzeczy” (2016 nr 3, 2016 nr 7), które pokazują „nadzorców z Brukseli” oraz Jarosława Kaczyńskiego w roli Supermana ratującego Polskę przed Europą (artykuły, które są zapowiadane tym obrazem, zupełnie na poważnie sięgają do tego porównania $\left.{ }^{30}\right)$.

Kryzys uchodźczy sprawił, że Europa (a zwłaszcza Niemcy) zaczęła być utożsamiana z „islamizacją”. W okresie kampanii wyborczej intencja islamizacji została przypisana też Platformie Obywatelskiej (il. 4). Już po wyborach parlamentarnych Ewa Kopacz przegrała proces, który wytoczyła tygodnikowi „W Sieci” za okładkę (2015 nr 38), przedstawiającą ją w burce, przepasaną laskami dynamitu i z podpisem: „urządzi nam piekło na rozkaz Berlina”. Skądinąd retoryka „germanizacji” PO sprawdziła się już w 2005 roku - wówczas

29 Zob. http://www.deutschlandfunk.de/regionalwahlen-in-frankreich-frau-le-pen-ist-wahlpolitisch.694.de.html?dram:article_id=339718 (12.09.2016).

30 R.A. Ziemkiewicz Polski wirus wolności, "Do Rzeczy” 2016 nr 7; O. Bault Czego się boi europejska lewica?, "Do Rzeczy” 2016 nr 7. 
sprawa „dziadka z Wehrmachtu" przyczyniła się do przegranej Donalda Tuska w wyborach prezydenckich. Różnica między tamtą kampanią wyborczą a ostatnią polegała jednak na tym, że jedenaście lat temu walka toczyła się raczej na słowa. Poza "znikającą lodówką" w spotach PiS niewiele było silnych akcentów wizualnych. Tym razem natomiast slogany wyborcze i oskarżenia wobec konkurencyjnych partii wspierane były bogatym materiałem ilustracyjnym, kolportowanym przez prawicową prasę ilustrowaną oraz Internet.

Chwyty retoryczne, sugerujące najazd "islamistów" czy wręcz terrorystów, w prosty sposób

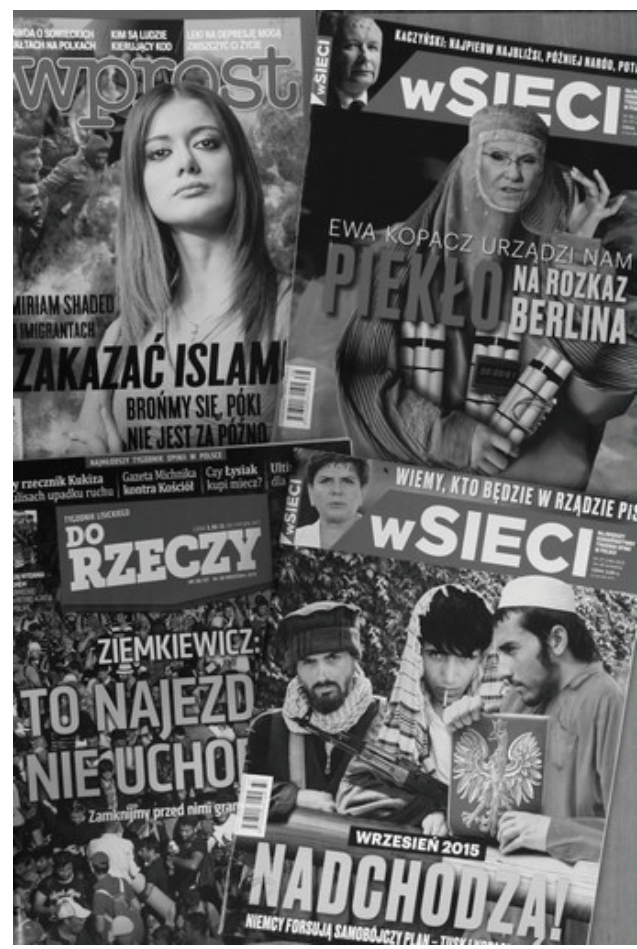

il. 4.: GROŹBA ISLAMIZACJI. Górny rząd lewa strona: "Wprost” 2016 nr 10, górny rząd prawa strona: „W Sieci” 2015 nr 38, dolny rząd lewa strona: „Do Rzeczy” 2015 nr 38, dolny rząd prawa strona: „W Sieci” 2015 nr 37. Fot. własna.

umacniały argumentację o Unii Europejskiej jako „obcym”, który zagraża Polsce. Co ciekawe, także w tym wypadku nie zabrakło analogii historycznych, gdyż uchodźcy porównywani byli do najeźdźców z okresu II wojny światowej. „W Sieci” (2015 nr 37) przedstawiło trzech mężczyzn, którzy strojem, kolorem włosów czy brodą wpisywali się w stereotyp "islamisty” i stali przy biało-czerwonym szlabanie, jak niemieccy żołnierze na znanej fotografii propagandowej z 1939 roku. Ponieważ okładka ukazała się we wrześniu, gdy media często przypominają obrazy z początku II wojny światowej, skojarzenie z atakiem III Rzeszy na Polskę było oczywiste.

Oprócz II wojny światowej do centralnych tematów historycznych wizualizowanych przez prawicową prasę należy komunizm. W tym kontekście do łask wrócił stereotyp żydokomuny. Na okładce „Do Rzeczy” (2016 nr 21) Piotr Zychowicz otwarcie nawoływał do przeciwstawiania się „politycznej 
poprawności". Ilustracja przedstawiała dwie zwrócone ku sobie stereotypowe postaci: Żyda (z długą brodą i pejsami) oraz komunistę (w charakterystycznej czapce z pięcioramienną gwiazdą). W ten sposób tygodnik wznowił retorykę mediów „niepokornych”, które przełamują społeczny common sense, wypracowywany stopniowo po 1989 roku. Antysemicki obraz należał jednak do wyjątków. Najczęstszymi grzechami z czasów komunistycznych są w świetle tej ikonografii współpraca z SB oraz tzw. zdrada okrągłego stołu. Ujawnienie zawartości tzw. szafy Kiszczaka poskutkowało m.in. serią obrazów, które interpretowały fakty opisane w dokumentach (il. 5). Pominąwszy

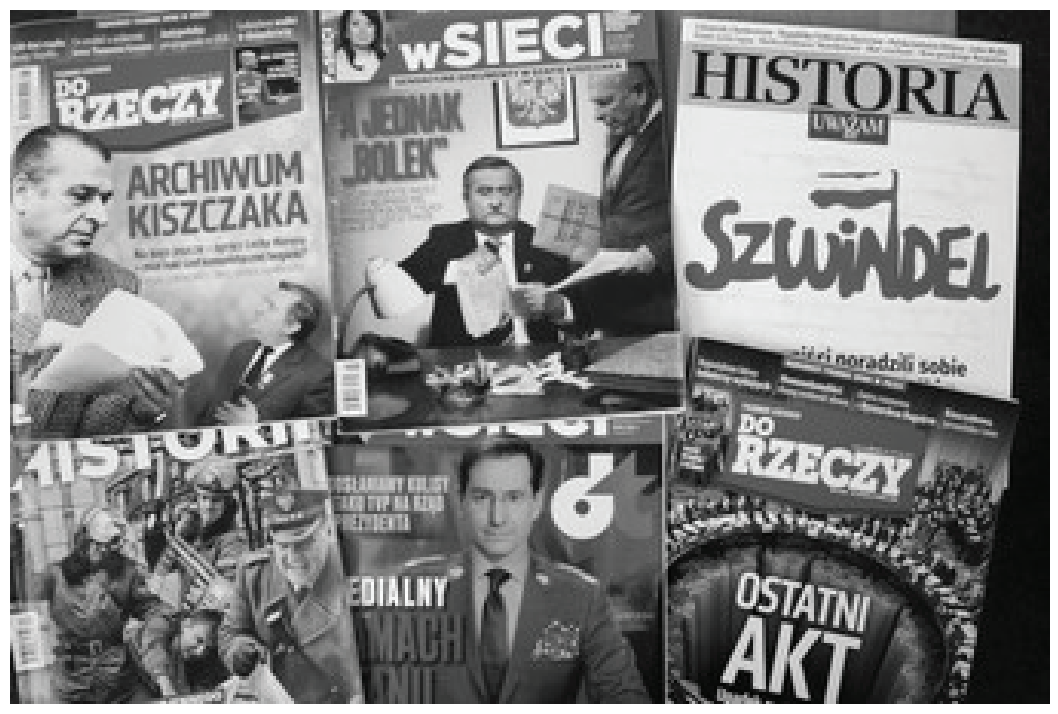

il. 5.: POSTKOMUNIZM. Górny rząd lewa strona: „Do Rzeczy” 2016 nr 8, górny rząd środek: „W Sieci” 2016 nr 8, górny rząd prawa strona: „Uważam Rze Historia” 2015 nr 2, dolny rząd lewa strona: „W Sieci Historii” 2015 nr 12, dolny rząd środek: „W Sieci” 2015 nr 52, dolny rząd prawa strona: „Do Rzeczy” 2016 nr 9. Fot. własna.

oczywiste sugestie o domniemanym szantażowaniu Wałęsy przez Kiszczaka („Do Rzeczy” 2016 nr 8) czy niszczeniu teczki „Bolka” przez byłego przewodniczącego „Solidarności” („W Sieci” $2016 \mathrm{nr}$ 8), warto zwrócić uwagę na fakt, że same akta, mimo że szyblko opublikowane przez IPN, nie były obszernie cytowane przez prasę prawicową. Były natomiast interpretowane - nie tylko w artykułach i komentarzach, ale też w obrazach i ilustracjach. Czytelnik, lub w tym wypadku widz/oglądający, nie musiał już zatem przedzierać się przez suche dokumenty (w zasadzie w ogóle nie musiał czytać) i na pierwszy rzut oka poznawał ich sens, zrekonstruowany dla niego przez obie redakcje. W ten 
sposób skomplikowane treści i złożone procesy historyczne sprowadzane są do chwytliwego, jednoznacznego i prostego obrazu.

Konsekwencją pokazania Wałęsy jako zdrajcy, okrągłego stołu zaś jako „układu z komuną" jest brak uznania transformacji politycznej w Polsce po 1989 roku, co sprowadza się do nośnej idei „postkomunizmu”. W tej wizji komunizm wciąż trwa, a komunistami są przeciwnicy prawicy. Idąc tym tropem, Wojciech Cejrowski nazywał w „Do Rzeczy” (2016 nr 14) współczesną opozycję: „komuchami, synami komuchów, wnukami komuchów i neokomuchami”, co zostało utrwalone w formie sloganu na okładce. Magazyn „W Sieci” (2015 nr 52) pokazywał natomiast Piotra Kraśkę, znanego w środowiskach prawicowych jako jedno z ,resortowych dzieci” i zwolennik KOD-u (tego dowiadujemy się z kartki, która leży przed nim), w stylizacji na Wojciecha Jaruzelskiego z dnia ogłoszenia stanu wojennego. Okładka ukazała się pod koniec grudnia 2015 roku, co zapewne wzmocniło skojarzenia z obrazami widocznymi w publicznej ikonosferze dwa tygodnie wcześniej.„W Sieci” nawiązywało tutaj do okładki „Polityki” (2014 nr 50), wcześniejszej dokładnie o rok, która przedstawiała Jarosława Kaczyńskiego w ciemnych okularach, co w oczywisty sposób sugerowało podobieństwo do gen. Jaruzelskiego. W tej konkurencji „Newsweek Polska” (2016 nr 30) też nie pozostał w tyle, publikując okładkę opartą na tym samym chwycie retorycznym, tylko wymierzonym w TVP po zmianie ustawy medialnej. Na czarnym tle umieszczono cztery telewizory, a w nich było widać Jarosława Kurskiego oraz głównych moderatorów „Wiadomości" w generalskich mundurach.

Obrazom „obcych”, „wrogów” przeciwstawiano obrazy „,swoich”, „, bohaterów”. Dla „W Sieci” (2015 nr 39) są to Viktor Orbán i Jarosław Kaczyński, którzy - jak głosi tekst na okładce - „bronią Europy przed szaleństwem lewicy $\mathrm{i}$ islamistami". W tle zaś widać husarię. Choć obaj politycy przedstawieni są w dość klasycznej konwencji (w półzbliżeniu, ubrani w garnitury i zwróceni twarzą do obiektywu), to zestawienie z bojownikami na koniach umieszcza ich w tradycji Europy walczącej przed najazdami ze Wschodu, sugeruje analogie do Jana III Sobieskiego i odsieczy wiedeńskiej z 1683 roku. Ten obraz wpisuje się w szerszą retorykę „obrony” Europy. Kilka dni po publikacji tego numeru, w najgorętszym okresie kampanii przed wyborami parlamentarnymi, Jarosław Kaczyński wygłosił słowa o tym, że „różnego rodzaju pasożyty, pierwotniaki, które nie są groźne w organizmach tych ludzi, mogą tutaj być groźne"31. Pytany

31 Zob. http://www.newsweek.pl/polska/jaroslaw-kaczynski-o-uchodzcach,artykuly,372175,1. html (13.09.2016). 
o tę wypowiedź Witold Waszczykowski bronił prezesa PiS w swoim pierwszym zagranicznym wywiadzie po objęciu urzędu Ministra Spraw Zagranicznych: „we accept this language, because this is not a language of hate, this is a language of warning"32 - mówił. Rysuje się z tego klarowny obraz świata, w którym prawicowi politycy bronią Europy przed najazdem barbarzyńców i przed lewicą, która nie dostrzega prawdziwego zagrożenia.

Reinterpretacje historii późnego PRL nie ograniczają się do sporu o rolę Wałęsy i znaczenie obrad okrągłego stołu. W nowym świetle przedstawiana jest także działalność braci Kaczyńskich. „W Sieci” (2016 nr 10, 2016 nr 26) opublikowało aż dwie okładki przedstawiające Jarosława i Lecha Kaczyńskich w roli bohaterów „Solidarności”. Na jednej z nich widzimy ich na tle transparentu z nazwą związku, na pierwszym planie widnieje napis: „Tak walczyli Kaczyńscy. SB chciała internować także Jarosława. Mamy dokumenty”, pod spodem przedstawione są teczki z materiałów operacyjnych. Na drugiej okładce ponad okrąłym stołem unoszą się, niczym duchy, wizerunki Adama Michnika, Tadeusza Mazowieckiego, Jarosława Kaczyńskiego, Jana Olszewskiego i Lecha Wałęsy. Największa postać, w środku kręgu, to Lech Kaczyński. Z czarno-białego kolażu wybija się biało-czerwony znaczek „Solidarności” w klapie jego marynarki. Co ciekawe, tylko bracia Kaczyńscy pokazani są en face, wszystkie inne postaci zaś widoczne są lekko z ukosa, co może sugerować, że mają coś do ukrycia ${ }^{33}$. Okładka zapowiada teksty o autobiografii Jarosława Kaczyńskiego, w której „odsłania [on] początek walki o Polskę z układem Michnika". Dokonuje się tu zatem przewartościowanie narracji o najnowszej historii Polski. Obrady okrągłego stołu już nie są negocjacjami po bezkrwawej rewolucji, tylko „układem”, w którym Adam Michnik (w domniemaniu: „Gazeta Wyborcza") rzekomo przejął władzę do spółki z komunistami.

\section{IV}

Omówione tu obrazy stanowią obecnie trwały element polskiej ikonosfery, popierany prawdopodobnie przez około 40\% społeczeństwa (zakładając, że czytelnicy „W Sieci”, „Do Rzeczy” i „Uważam Rze” rekrutują się głównie z wyborców PiS i Kukiz 15), a także przez środowiska rządowe. Motywy polskiego bohaterstwa oraz wrogości wobec komunizmu, Niemców i Rosjan dostępne są w tysiącach egzemplarzy i reprodukowane przez różne media:

Zob. http://www.bbc.co.uk/programmes/po37xskl (10.05.2016).

33 Za spostrzeżenie to dziękuję Katarzynie Bojarskiej. 
prasę, telewizję, portale internetowe, t-shirty, naklejki itd. Okładki tygodników i miesięczników ilustrowanych stanowią ledwie niewielki wycinek tej historyzującej ikonosfery.

Niektóre wątki powracają cyklicznie ze zwiększoną siłą: powstanie warszawskie w sierpniu, wybuch II wojny światowej we wrześniu, a stan wojenny w grudniu. W ten sposób budowana jest spójna i wciąż powtarzana opowieść o polskiej historii, posługująca się sprawdzonymi technikami „przezroczystego" montażu oraz wykorzystująca uniwersalne schematy narracyjne popkultury. Utrwaleniu podziału na „dobrych" $i$ „złych”; „naszych" $i$,waszych" służą zarówno cytaty z powszechnie znanych utworów kulturowych, jak i wpisywanie poszczególnych motywów w jubileuszowe cykle polskiej historii. Przeszłość konstruowana na okładkach prasy prawicowej nie odchodzi w niepamięć, lecz podlega nieustannym powtórzeniom. „W Sieci” i „Do Rzeczy” nie obawiają się wielokrotnego wykorzystania tego samego motywu w krótkim czasie: w okresie bezpośrednio przedwyborczym magazyn „W Sieci” aż cztery razy otwierał wydania od tematu uchodźców, a „Do Rzeczy” w lutym 2016 roku dwa razy z rzędu piętnował Lecha Wałęsę i ustalenia okrągłego stołu na okładce. Repetytywność niektórych motywów czyni z nich punkty krystalizacji lub - posługując się językiem Pierre'a Nory - miejsca pamięci ${ }^{34}$ nowej świadomości historycznej, kształtowanej na naszych oczach.

Trudno natomiast mówić, by prawicowa ikonografia stanowiła formę przeciwhistorii. Po pierwsze, afirmatywna historiografia i historiofotia od lat stanowią mainstream polskiego dyskursu o przeszłości. Po drugie, w tych opowieściach i obrazach do głosu nie dochodzą grupy wykluczone. Przeciwnie, są coraz bardziej spychane na margines dyskursu, a takie słowa jak „gender” czy „Żydzi” należą do negatywnego słownika polskiej prawicy. W tej grze podaży i popytu na obrazy (można założyć, że pojawianie się określonych motywów jest reakcją na istniejące zapotrzebowanie) istotną rolę odgrywają emocje. Wydaje się, że w projektach prawicowych okładek ważniejsze od informowania o zawartości poszczególnych numerów jest wywoływanie silnych afektów. Kulminacyjnym punktem tej strategii był numer „W Sieci” (2015 nr 42) z tygodnia, gdy odbywały się wybory parlamentarne w 2015 roku. Przedstawiał on Józefa Piłsudskiego z zaciśniętą pięścią, stojącego obok urny wyborczej oraz napis: „Wybory 2015. Bić k... i złodziei. Program Józefa Piłsudskiego nadal aktualny". Od lat 9o. XX wieku Piłsudski jest jedną z częściej przywoływanych postaci w polskiej polityce, publicystyce i historiografii (co

Por. K. Kończal Miejsce pamięci, w: Modi memorandi..., s. 230. 
jest jednym z dowodów na to, jak silnym i trwałym miejscem pamięci jest jego postać). W tym wypadku nie chodzi jednak o pokazanie go w roli wzoru patriotyzmu, lecz o zbudowanie ramy dla prostego przekazu, że dotychczasowy rząd to „k... i złodzieje”, których należy zniszczyć - również fizycznie. Marszałek służy zatem delegitymizacji starej władzy i zapowiada nadejście nowej.

Publiczna ikonosfera przyczynia się do utrwalenia hegemonii afirmatywnego dyskursu historycznego. Wizualizuje i multiplikuje treści, formułowane w formie pisemnej czy mówionej. Wykorzystuje "agresywne momenty” (by użyć języka Eisensteina), sięgając do motywów z II wojny światowej i komunizmu. Wrogowie są zatem często przedstawiani w roli nazistowskich najeźdźców lub komunistycznych zdrajców, przyjaciele zaś to bohaterscy patrioci. Nowe obrazy, które powstają z takich zestawień, nie wspierają racjonalnych argumentacji, opartych na faktach i badaniach naukowych. Ich zdanie polega raczej na wywoływaniu silnych, skrajnych emocji, takich jak strach (przed uchodźcami, Niemcami, Rosjanami, Żydami) i duma (z Polski, jej historycznych zwycięstw, przywódców). Łącząc przeciwieństwa, obrazy te eskalują konflikt - najpierw w przestrzeni medialnej, później w przestrzeni społecznej. Produkują wiedzę o historii, która szybko się utrwala. Tak skonstruowana przeszłość jest bowiem prosta i zbudowana na binarnej opozycji „dobrzy - źli", epatuje silnymi emocjami i oferuje jednoznaczne identyfikacje. Złożone problemy historyczne redukowane są zaś do schematycznych podziałów na "obcych" i „naszych".

\section{Abstract}

\section{Magdalena Saryusz-Wolska}

UNIVERSITY OF ŁÓDŹ, GERMAN HISTORICAL INSTITUTE WARSAW

The Public Construction of History: The Past in Right-Wing Iconography

Saryusz-Wolska analyses covers of conservative weekly magazines to examine contemporary Polish right-wing iconography. Focusing on historical motifs, she highlights the mechanisms behind the construction of 'us' and 'them' or 'enemies' and 'friends' in visual discourses. Drawing on voices from both politics and the media, these rightwingers call attention to perceived threats - such as Europe, Germany, Russia, or refugees. The magazine covers studied here mirror those'threats' by drawing on a simplistic and 
emotional symbolism. The European Union is likened to Nazism, Angela Merkel to Hitler. We also see collages that draw on historical iconography but in a contemporary context, such as refugees forcing Poland's borders in the place of Wehrmacht soldiers. Thus the iconography of the right creates simplistic parallels and suggests false analogies.

\section{Keywords}

right-wing press, right-wing iconography, public iconosphere, visual history, images of the enemy

Dodatkowe informacje o okładkach czasopism:

il. 1.:Obsesje nazizmu. „Uważam Rze Historia" 2015 nr 3, 2015 nr 11, 2016 nr 2, projekt graficzny czasopisma: Malwina Użarowska, brak informacji o autorach okładki.

il. 2.:Europa jako wróg. „Do Rzeczy” 2016 nr 3, okładka: Midas; „W Sieci” 2016 nr 7, okładka: Michał Korsun, fot. Andrzej Wiktor; „Uważam Rze Historia” 2015 nr 11, projekt graficzny czasopisma: Malwina Użarowska, brak informacji o autorach okładki; „Do Rzeczy” 2016 nr 7, okładka: Beata Zawrzel/Reporter, Shutterstock, Montaż: Sunday, Jan.

il. 3.:Nadzór z Niemiec (i Rosji). „Wprost” 2016 nr 2, okładka: Studio Wprost, fot. Universal History Archive/ Getty Images/Therry Monasse/Polaris/East News, Matthew Mirabelli/AFP, Sean Gallup/Myriam Voleg/AP, Action Press; „W Sieci” 2016 nr 2, okładka: Michał Korsun, fot. Andrzej Wiktor, Photoshot/Reporter, 360.B/Shutterstock.com.

il. 4.:Groźba islamizacji. „Wprost” 2016 nr 10, okładka: Studio Wprost, foto: Marcin Kaliński, Istock, Reuters, Alexandros Avramidis/Forum, Reuters/Zaubier Soussi/Forum; "W Sieci” 2015 nr 38, projekt graficzny czasopisma: Michał Korsun, okładka: fot. Andrzej Wiktor, Muhamad Sadiq/ EPA/PAP, Shutterstock; „Do Rzeczy” 2015 nr 38, szef studia graficznego: Mariusz Daruk-Skarbek, Reuters/Forum; „W Sieci” 2015 nr 37, projekt graficzny czasopisma: Michał Korsun, okładka: fot. Jenny Mathews / In Pictures / Corbis / Shutterstock, Adam Chełstowski.

il. 5.:Postkomunizm. „Do Rzeczy” 2016 nr 8, okładka: K. Wójcik/Forum, W. Druszcz/Reporter, montaż: Jan; „W Sieci” 2016 nr 8, okładka: PAP/Tomasz Gzell, TVP/PAP/Jan Bogacz/ Ireneusz Sobieszczuk, Andrzej Wiktor, Shutterstock; „Uważam Rze historia” 2015 nr 2, projekt graficzny czasopisma: Malwina Użarowska, brak informacji o autorach okładki; „W Sieci Historii” $2015 \mathrm{nr}$ 12, projekt okładki: Michał Korsun, fot. Andrzej Wiktor, Rekonstruktorzy z GRF Bemowo oraz reko.waw.pl; „W Sieci” 2015 nr 52, okładka: fot. PAP/Wojciech Krysiński, Witktor Rozbicki, Niemiec/AKPA, Andrzej Wiktor; „Do Rzeczy” 2016 nr 9, okładka: Krzysztof Pawela/Shutterstock, montaż: Midas. 